\title{
25 Research Soure \\ Categorization of Different Clamp Types Used For The Endurance Test of Human Grafts - A Systematic Review
}

\section{Denes Farago ( $\nabla$ farago@mogi.bme.hu )}

Budapest University of Technology and Economics

Blanka Kozma

University at Buffalo, State University of New York

Rita Maria Kiss

Budapest University of Technology and Economics

\section{Research Article}

Keywords: tendon, biomechanical endurance test of tendon, clamp type, mechanical properties

Posted Date: September 22nd, 2021

DOI: https://doi.org/10.21203/rs.3.rs-758760/v1

License: (a) (i) This work is licensed under a Creative Commons Attribution 4.0 International License. Read Full License 


\section{Abstract}

\section{Background}

The use of tendon allografts for orthopedic repair has gained wide acceptance in recent years, most notably in anterior cruciate tendon reconstruction. Multiple studies support the use of tendon allografts and the benefits of its use are well accepted and understood. One of the important criteria of the use of tendon allografts is statistically similar histological and biomechanical properties to autographs. Five major scientific literature databases (Web of Science, Science Direct, Scopus, PloS ONE, Hindawi) and additional sources were used.

Results

The objective of this systematic literature review is to investigate and categorize existing clamps used in the determination of the biomechanical properties (maximum load, maximum strength, modulus of elasticity, ultimate strain, stiffness) of tendons. Studies had to use an endurance test of tendons and clamps in detail. The database search and additional sources resulted in 274 records. 216 records eliminated during the screening for various reasons. The number of articles used in the final synthesis was 58 . Search for publications dated between 1991 and Oct $31^{\text {st }}, 2020$. A variety of clamps for use during the endurance test of tendons were identified and categorized according to the temperature used during the measurement. The clamps are divided into three groups: room temperature, cooled or heated clamps.

Conclusions

On the basis of the systematic literature review, mechanical parameters determined by usage with cooled clamps proved to be more reliable than with those at room temperature and with heated clamps. The main advantage of the cooled clamps is that there is no limit to the type and length of the tendon. This study provides an overview of clamps and does not represent the modernity of any method.

\section{Background}

The use of tendon allografts for orthopedic repair has gained wide acceptance in recent years, most notably in anterior cruciate tendon reconstruction [1]-[3]. Multiple studies support the use of tendon allografts and the benefits of its use are well accepted and understood [2]; [4]-[7]. Specifically, these benefits include decreased surgical time, decreased surgical morbidity and unaltered mechanics secondary to harvesting. Furthermore, animal and human studies have shown that soft tissue allografts are statistically similar to autografts on a histological and biomechanical basis [8]-[10].

Anterior cruciate ligament $(\mathrm{ACL})$ reconstruction is a common procedure in orthopedic practice. One of the most important decisions for the surgeon to make is the right choice of graft. Although autografts have proven to be capable and showed good clinical outcomes, graft harvest can cause persistent pain at the harvest site and a limited range of motion [11]-[14]. Therefore, allograft use has significantly increased in the last decades. Since it eliminates donor-site morbidity, and albeit its use is associated with higher costs, it 
remains a viable option, especially in revision cases. In order to ensure that there is a minimal biomechanical difference between the ACL and the graft, the biomechanical properties need to be tested so that we can choose which tendons can be good substitutes [7], [15]. The tendons are subjected to tensile testing, which can be static or dynamic. From these we get a force-elongation diagram, which can be calculated based on, for example the Young's modulus of elasticity [16]-[18].

The purpose of a clamp is a proper fixation technique for allograft endurance tests, and adapt it to be compatible for the loading machine [10], [19]. The main problem with tendon clamps is that it is hard to maintain the high pressure needed to provide enough friction force between the tendon and the clamp to resist a large tensile load, and at the same time to reduce the cutting effect of the clamp (Shi D, Wang D, Wang C, Liu A: A novel, inexpensive and easy to use tendon clamp for in vitro biomechanical testing. Med. Eng. Phys. 34, 516-520 (2012)) [7], [20]-[23].

Various clamps have been developed for the assessment of the endurance test. These clamps are usually specific for measurement methods, thus, the results of the measurement methods are difficult to compare [1], [8], [11]-[15], [24]-[25].

\subsection{Aim of study}

The literature of the effect of the sterilization method on the material properties of the tendon is well researched and discussed [72-76]. Nevertheless, there are no systematic reviews on the subject that would provide guidance on the clamps used for the measurements. The objective of this study is to investigate and categorize existing clamps used in the determination of the biomechanical properties.

\section{Materials And Methods}

\subsection{Search strategy}

\subsubsection{Material Identification}

This systematic review was carried out in keeping with the PRISMA guidelines [26]. A search was conducted for publications dating between 1991 and October 31st 2020 through five electronic databases (Web of Science, Science Direct, Scopus, PubMed, PloS ONE, and Hindawi). Key search terms used with Boolean conjunction included: tendon, allograft tendon, biomechanical pull-out testing, mechanical properties, and additional synonyms of these terms. Search terms were modified according to the syntax requirements of each database. (Table 1)

As an example, we highlight the electronic search for the Science Direct database, which is shown below. These terms were added into the Advanced search option, using the 'All fields' option: (allograft tendon OR tendon) AND (biomechanical pull-out testing OR stiffness OR strength OR mechanical properties OR modulus OR ensurence test). The search was limited to journal publications. Publication date limits were set to from 1991, with the search performed on Oct 31th, 2020. The search of the Science Direct database yielded 140 records. Key search terms were identified and agreed upon by DF and RMK; electronic search 
and downloading of results were conducted by DF. Screening, eligibility check of materials and date extraction were carried out by DF and BK [77].

\subsubsection{Screening materials}

After removing the duplicates, the identified publications were screened based on their title and their abstracts. Publications of exclusively theoretical work or Materials of purely theoretical work or with topics deviating from the aim of study were excluded.

\subsubsection{Eligibility check of materials}

In order to confirm eligibility for the study, the reviewers defined the inclusion and exclusion criterias. The publications had to meet each inclusion criterion to be incorporated in the final synthesis (Table 1). If a study failed to meet any inclusion criteria, or met an exclusion criterion, it was excluded. The criteria were carefully chosen to ensure a quality assessment of the material to a certain extent, i.e., the methods used had to be well communicated and the evaluation of measurement results had to be objective.

\subsubsection{Data extraction}

In accordance with the focus of this review, the final synthesis of the collected types of clamps included extracted relevant information on the evaluation of mechanical properties. The collected information from the articles included a) author and date, b) name of clamp, c) type preloading (dynamic and static) d) type of endurance test, e) type of tendon, f) type of clamps, and g) measured and calculated parameters.

Table 1

Inclusion and exclusion criteria

\begin{tabular}{|lll|}
\hline Viewpoints & Inclusion & Exclusion \\
\hline $\begin{array}{l}\text { Tendon and } \\
\text { endurance test } \\
\text { and clamp }\end{array}$ & $\begin{array}{l}\text { Studies which included tendon and } \\
\text { endurance test and clamp in their } \\
\text { experimental procedures. }\end{array}$ & $\begin{array}{l}\text { Studies which only included a tendon } \\
\text { measurement method without any type } \\
\text { of clamp. }\end{array}$ \\
\hline $\begin{array}{l}\text { Description of } \\
\text { tendon and } \\
\text { endurance test } \\
\text { and clamp }\end{array}$ & $\begin{array}{l}\text { Studies with detailed descriptions of the } \\
\text { tendon and endurance test and clamp } \\
\text { and the experimental process that was } \\
\text { followed. }\end{array}$ & $\begin{array}{l}\text { Studies without detail or incomplete } \\
\text { descriptions of the clamp and endurance } \\
\text { test and the experimental process that } \\
\text { was followed. }\end{array}$ \\
$\begin{array}{lll}\text { Assessment of } \\
\text { results }\end{array}$ & $\begin{array}{l}\text { Studies with objective result } \\
\text { assessment based on measurable } \\
\text { parameters. }\end{array}$ & $\begin{array}{l}\text { Studies with subjective } \\
\text { scoring/assessment of results, not } \\
\text { (entirely) based on measurable } \\
\text { parameters. }\end{array}$ \\
\hline
\end{tabular}

\section{Results}

The search of the database source gave 366 results (Fig. 1). Removing duplications and unavailable abstracts, 274 literatures remained. When screening the titles and the abstracts, an additional 56 records were excluded, due to not fitting the scope. The remaining 218 articles have been read in their entirety. Of these studies, 160 were excluded with justifications of not meeting the eligibility criteria, and 6 publications 
were literature review articles related to sterilization methods. These review articles had a different scope from our current study. The number of articles included in the final synthesis was $58(n=58)$.

Articles have been excluded for the following reasons. Many studies included a task that was outside the scope of our study. If multiple studies used equivalent clamp type with the same mechanical test, the latest study was included (63 articles) [77]. Several articles did not describe a detailed measurement setting and type of clamp used and were therefore excluded (84 articles) [77]. The evaluation of few articles was subjective (6 articles), and there were also clinical case ( 7 articles).

\subsection{Type of clamps}

The systematic review aimed at creating a comprehensive catalogue of existing clamps used in the determination of biomechanical properties. These studies evaluated what kind of impact the type of clamp had on the measurement [27-30], [32], [34], [36-40], [42], [44], [46-48], [50-51], [56-60], [65-71]. A variety of clamps for use during the endurance test of tendons were categorized according to the temperature used during the measurement. The clamps are divided into three groups: room temperature clamps [30], [34], [36] [38], [40], [42], [44], [47-48], [50], [58-60], [66-68], cooled clamps (under room temperature with ice, cooled air, dry ice or liquid nitrogen) [27-29], [32], [46], [51], [56], [65], [69] and heated clamps (over room temperature with heated air, heated fluids) [37], [57], [70-71]. All three groups are factory-made and customdesigned clamps.

\subsubsection{Room temperature clamps}

Measuring at room temperature is a quick test because it requires the least amount of preparation as there is no need for dry ice, liquid nitrogen, heating, etc. Sufficient force is applied during the measurement to prevent tendon slippage, but no transverse tension is created during the capture of the tissues, which yields invalid results.

One of the room temperature clamps is the U-shaped frame (Fig. 2), which can be used for the measurement of the tendon together with the bones. The bone was secured in custom-designed fixation frame with screws. The precision of the drill was ensured by an outer polyethylene mold. [47], [50] In a special case, the bone is inserted into a separately moulded block while the free tendon is pulled by the clamp. The solution allows to investigate the relationship between bone and tendons. (Fig. 3). [67]

Some researchers used custom-designed clamps, where the bone block was secured with either interface polymethylmethacrylate-PMMA or polyurethane [36] (Fig. 4). A solution can also be applied where the natural tendon is fixedby a bone block at one end and by a pneumatic clamp to prevent slippage [42] (Fig. 5). Here, it is particularly important to prevent slippage between the clamp and the tendon, therefore the surface is scratched by sand spraying in several cases.

A special case is when wedge-grip clamp use involves silicone or some kind of artificial resin at both ends to ensure the connection between clamp and tendon [34], [38], [68] (Fig. 6). 
Several articles use polymer-encapsulated aluminum clamps to achieve better adhesion between the tendon and the clamp (Fig. 7). One of the advantages of the system is that it can be expanded by strain gauges [40], [48], [59], [60].

\subsubsection{Cooled clamps}

A basic condition for an appropriate measurement method is to prevent the tendon from slipping out of the clamp, therefore various methods are applied for establishing an adequate connection. One of the reasons for slippage is that the tendon is damp. Therefore it is expedient to continuously freeze the surroundings of the clamp, which naturally scratches the surface. It is expedient to use dry ice or liquid nitrogen for freezing. A disadvantage is that it is not easy to place the freezing substance in the surroundings of the clamp [27][29], [32], [46], [51], [56], [65], [69]. Particular care should be taken that the entire tendon is not completely cooled / frozen because thus the mechanical properties of the tendon are changed. A basic solution for all clamps is that the natural tendon (without the bone) is squeezed between two metal grips, and the two metal grips are fastened to each other by screws. Connection between the grips and the tendon is further increased by grooved metal or plastic inserts fixed on the internal surface of the grips [27]- [29], [32], [46], [51], [56], [65], [69]. In certain cases, the tendon and the clamp are congealed together, so they work together properly; furthermore, no slippage occurs between tendon and clamp and the tendon does not get torn near the clamp, either [28], [65]. This method can be used in case of tendons of different sizes and types.

However, one of the simplest solutions is that the clams or clamp inserts can be cooled separately before measuring, regardless of the tensile machine. In this case, they should be placed in a deep-freezer for at least 24 hours. The tendon is placed into the cooled clamp; the grips squeezing the tendon can be fixed in one or two rows (Fig. 8) [32], [69].

One of the major advantages of cooled clamp use is that factory clamps can be used; it is required to ensure continuous and adequate cooling by placing a chamber of appropriate size to the proper place [28], [65], (Fig. 9). The custom-designed screwed clamp can be made of aluminum plate with a dry ice chamber, where the dry ice can be replaced continuously for ensuring continuous cooling. (Fig. 10) [56].

\subsubsection{Heated clamps}

Measurements conducted in an environment of room temperature, using room-temperature or sooled clamps, greatly differ from the temperature of the natural surroundings of tendons $\left(37^{\circ} \mathrm{C}\right)$. Environment temperature presumably affects mechanical properties: more accurate results are yielded if tests are conducted at body temperature. In order to ensure this, it is expedient to use heated clamps [37], [57], [70], [71]. A disadvantage is that, contrary to cooled clamps, the connection between the clamps and the tendon is not improved, but it is also important that it is not deteriorated, either. In general, it is expedient to use a heated liquid for warming [57], [70]; heat insulation should be provided around both the clamps and the component to be examined (Fig. 11) [37]. The measurement can also be performed in a bath filled with heated liquid, which is continuously monitored. It is a basic requirement that the heated liquid should not 
deteriorate the properties of the tendon (Fig. 12) [57]. The circulation of the liquid simulates the behavior of the blood. (Fig. 13) [70].

\section{Discussion}

The clamp should be designed to prevent the slippage of the tendon from the clamp, but the clamping force should not change the tensile state of the tendon to be examined. The objective of this systematic literature review is to investigate and categorize existing clamps used in the determination of the biomechanical properties of tendons such as maximum load, maximum strength, modulus of elasticity, ultimate strain, and stiffness. A variety of clamps for use during the endurance test of tendons were categorized according to the temperature used during the measurement. The clamps are divided into three groups: room temperature, cooled and heated clamps. The data collected from the articles a) author and date, b) name of clamp, c) type preloading (dynamic and static) d) type of endurance test, e) type of tendon, f) type of clamps, and g) measured and calculated parameters. The data are summarized in Table 2.

The metal U-shaped frame (Fig. 2) allows for bone-tendon strength to be studied [47, 50]. This clamp also ensures stability of the tendon, not letting it slip out. Because the tendon is clamped tightly, tissue texture can be damaged. In several cases, capture is performed using natural bones (Figs. 2 and 3 ) or artificial blocks (bone cement, silicone, artificial resin) (Fig. 4) [36, 42]. Natural tendon ends can be captured by custom - generally pneumatic - clamps (Fig. 5, 7), or embedded in artificial material (Fig. 6) [34], [38]. All of these ensure that the tendon does not slip out, but both need to be monitored for the polymer to graft adhesion [34], [38], [40], [59-60]. In those cases, the force awakening between the clamping heads ensures the success of the measurement [34], [36], [38], [40], [42] [59-60]. Natural and artifical blocks or hydraulic presses keep the tendon in place. [36], [42].

The wedge-grip clamp and the aluminum grips with polymer liners and the strain gauge clamp are similar (Figs. 6 and 7); however, adhesion between the polymer and the tendon can be monitored [34], [38], 40], [59], [60]. Advantages of room temperature clamps include easy usage and no requirement for any measurement preparation. The disadvantage is that room temperature clamps can damage tendon texture, can cause the tendon to tear at the point of fixation, and the tendon can slip out.

In multiple research, cooled clamps are used for measuring the biomechanical properties of a tendon [28], [32], [56], [65], [69]. A great advantage of frozen clamps is that surfaces are naturally made coarse by freezing, which assists in establishing an appropriate connection between the clamp and the tendon. The solution is relatively simple: the tendon can be fastened by two metal grips fixed by screws. The first type of cooling is freezing the clamp before testing (Fig. 8). This requires a freezer that can freeze at $-70^{\circ} \mathrm{C}$ to $-80^{\circ} \mathrm{C}$. The frozen clamp also has to be attached to the machine. The tendon takes on the clamp's temperature over time.

The clamps shown in Figs. 9 and 10 use a dry ice container for cooling. The dry ice container allows for the tendon and the clamp to be cooled at the same time. Dry ice needs to be added during measurements, as it evaporates over time [28], [56], [65]. Both of these types of cooled clamps stop the tendon from slipping out. 
Cooled clamps allow for the tendon to freeze at the point of fixation, causing the tendon to tear at the weakest point [32], [69].

Heated clamps are required to be used for measurements at human body temperature $\left(37^{\circ} \mathrm{C}\right)$ [28], [32], [37], [56-57], [65], [69-70]. Leading-edge measurement designs (Fig. 13) can also imitate a human body environment (temperature, blood circulation). [70]. Heated clamps have the same disadvantages as room temperature clamps; the tendon can easily slip out, can be damaged by the clamp, or tear at the point of fixation [37], [57], [70]. 
Table 2

Overview of clamps

\begin{tabular}{|c|c|c|c|c|c|c|}
\hline $\begin{array}{l}\text { Name of } \\
\text { clamp }\end{array}$ & References & $\begin{array}{l}\text { Pre- } \\
\text { loading } \\
\text { type }\end{array}$ & $\begin{array}{l}\text { Type of } \\
\text { endurance } \\
\text { test }\end{array}$ & Type of tendon & $\begin{array}{l}\text { Type of } \\
\text { clamp }\end{array}$ & $\begin{array}{l}\text { Measured } \\
\text { and } \\
\text { calculated } \\
\text { parameters }\end{array}$ \\
\hline $\begin{array}{l}\text { Metal U- } \\
\text { shaped } \\
\text { frames }\end{array}$ & 47,50 & dynamic & static & $\begin{array}{l}\text { sheep patellar } \\
\text { tendon }\end{array}$ & $\begin{array}{l}\text { room } \\
\text { temperature }\end{array}$ & $\begin{array}{l}\text { failure } \\
\text { stress, } \\
\text { failure } \\
\text { strain, } \\
\text { normalized } \\
\text { stiffness, } \\
\text { energy to } \\
\text { failure }\end{array}$ \\
\hline $\begin{array}{l}\text { Custom } \\
\text { designed } \\
\text { clamps }\end{array}$ & 67 & static & static & $\begin{array}{l}\text { canine patella- } \\
\text { ligament-tibia }\end{array}$ & $\begin{array}{l}\text { room } \\
\text { temperature }\end{array}$ & $\begin{array}{l}\text { failure } \\
\text { load, } \\
\text { stiffness }\end{array}$ \\
\hline $\begin{array}{l}\text { Factory } \\
\text { clamps }\end{array}$ & 36 & dynamic & dynamic & $\begin{array}{l}\text { human patellar } \\
\text { tendon }\end{array}$ & $\begin{array}{l}\text { room } \\
\text { temperature }\end{array}$ & $\begin{array}{l}\text { ultimate } \\
\text { elongation, } \\
\text { ultimate } \\
\text { stress, } \\
\text { ultimate } \\
\text { stiffness }\end{array}$ \\
\hline $\begin{array}{l}\text { Wedge } \\
\text { shaped } \\
\text { factory- } \\
\text { clamps }\end{array}$ & 42 & static & dynamic & achilles & $\begin{array}{l}\text { room } \\
\text { temperature }\end{array}$ & $\begin{array}{l}\text { maximum } \\
\text { stress, } \\
\text { maximum } \\
\text { strain, } \\
\text { modulus }\end{array}$ \\
\hline $\begin{array}{l}\text { Wedge-grip } \\
\text { clamps }\end{array}$ & 34,38 & dynamic & dynamic & $\begin{array}{l}\text { human patellar } \\
\text { tendon }\end{array}$ & $\begin{array}{l}\text { room } \\
\text { temperature }\end{array}$ & $\begin{array}{l}\text { failure } \\
\text { load, } \\
\text { stiffness }\end{array}$ \\
\hline $\begin{array}{l}\text { Aluminum } \\
\text { grips with } \\
\text { polymer } \\
\text { liners }\end{array}$ & $40,59,60$ & dynamic & dynamic & $\begin{array}{l}\text { human patellar } \\
\text { tendon }\end{array}$ & $\begin{array}{l}\text { room } \\
\text { temperature }\end{array}$ & $\begin{array}{l}\text { failure } \\
\text { load, } \\
\text { stiffness, } \\
\text { strain }\end{array}$ \\
\hline $\begin{array}{l}\text { Testing } \\
\text { configuration } \\
\text { for single- } \\
\text { strand and } \\
\text { double-strand }\end{array}$ & 32,69 & dynamic & $\begin{array}{l}\text { static and } \\
\text { dynamic }\end{array}$ & $\begin{array}{l}\text { tibialis anterior } \\
\text { and posterior }\end{array}$ & $\begin{array}{l}\text { cooled } \\
\text { temperature }\end{array}$ & $\begin{array}{l}\text { linear } \\
\text { stiffness, } \\
\text { ultimate } \\
\text { tensile } \\
\text { force, } \\
\text { tensile } \\
\text { modulus, } \\
\text { ultimate } \\
\text { tensile } \\
\text { strength, } \\
\text { ultimate } \\
\text { tensile } \\
\text { strain }\end{array}$ \\
\hline
\end{tabular}




\begin{tabular}{|c|c|c|c|c|c|c|}
\hline $\begin{array}{l}\text { Name of } \\
\text { clamp }\end{array}$ & References & $\begin{array}{l}\text { Pre- } \\
\text { loading } \\
\text { type }\end{array}$ & $\begin{array}{l}\text { Type of } \\
\text { endurance } \\
\text { test }\end{array}$ & Type of tendon & $\begin{array}{l}\text { Type of } \\
\text { clamp }\end{array}$ & $\begin{array}{l}\text { Measured } \\
\text { and } \\
\text { calculated } \\
\text { parameters }\end{array}$ \\
\hline $\begin{array}{l}\text { Custom } \\
\text { designed } \\
\text { clamps with } \\
\text { dry ice } \\
\text { chamber }\end{array}$ & 28 & dynamic & dynamic & $\begin{array}{l}\text { anterior and } \\
\text { posterior tibialis }\end{array}$ & $\begin{array}{l}\text { cooled } \\
\text { temperature }\end{array}$ & $\begin{array}{l}\text { failure } \\
\text { load, } \\
\text { failure } \\
\text { stress, } \\
\text { stiffness }\end{array}$ \\
\hline $\begin{array}{l}\text { Factory } \\
\text { clamps with } \\
\text { dry ice } \\
\text { chamber }\end{array}$ & 56 & dynamic & dynamic & $\begin{array}{l}\text { achilles, } \\
\text { quadriceps, } \\
\text { semitendinosus } \\
+ \text { gracilis, } \\
\text { tibialis anterior, } \\
\text { peroneus } \\
\text { longus }\end{array}$ & $\begin{array}{l}\text { cooled } \\
\text { temperature }\end{array}$ & $\begin{array}{l}\text { Young's } \\
\text { modulus } \\
\text { of } \\
\text { elasticity, } \\
\text { maximum } \\
\text { load, strain } \\
\text { at tensile } \\
\text { strength, } \\
\text { strain at } \\
\text { break }\end{array}$ \\
\hline $\begin{array}{l}\text { Clamp with } \\
\text { thermocouple }\end{array}$ & 37 & dynamic & dynamic & $\begin{array}{l}\text { bilateral patellar } \\
\text { tendon }\end{array}$ & $\begin{array}{l}\text { heated } \\
\text { temperature }\end{array}$ & $\begin{array}{l}\text { tensile } \\
\text { strength, } \\
\text { tensile } \\
\text { modulus }\end{array}$ \\
\hline $\begin{array}{l}\text { Custom } \\
\text { clamp in } \\
\text { testing } \\
\text { chamber }\end{array}$ & 57 & $\begin{array}{l}\text { static } \\
\text { and } \\
\text { dynamic }\end{array}$ & $\begin{array}{l}\text { static and } \\
\text { dynamic }\end{array}$ & $\begin{array}{l}\text { human patellar } \\
\text { tendon }\end{array}$ & $\begin{array}{l}\text { heated } \\
\text { temperature }\end{array}$ & $\begin{array}{l}\text { stiffness, } \\
\text { maximum } \\
\text { load }\end{array}$ \\
\hline $\begin{array}{l}\text { Custom } \\
\text { clamp in } \\
\text { biochamber }\end{array}$ & 70 & dynamic & dynamic & soleus tendon & $\begin{array}{l}\text { heated } \\
\text { temperature }\end{array}$ & $\begin{array}{l}\text { ultimate } \\
\text { tensile } \\
\text { stress, } \\
\text { elastic } \\
\text { modulus, } \\
\text { toughness }\end{array}$ \\
\hline
\end{tabular}

\subsection{Limitation}

This study focused on the investigation and categorization of existing clamps used in the determination of biomechanical properties. Due to the use of different tests and tendons, they were compared based on individual criteria. It is recommended that for subsequent tests, measurements be made only with refrigerated clamps. From the measurements made in this way, a meta-analysis of the results is obtained. This study provides an overview of clamps and does not represent the modernity of any method.

\section{Conclusion}

The objective of this systematic literature review is to investigate and categorize existing clamps used in the determination of the biomechanical properties of tendons such as maximum load, maximum strength, modulus of elasticity, ultimate strain, and stiffness. A variety of clamps for use during the endurance test of tendons were categorized according to the temperature used during the measurement. The clamps are divided into three groups: room temperature, cooled and heated clamps. a) author and date, b) name of 
clamp, c) type preloading (dynamic and static) d) type of endurance test, e) type of tendon, $f$ ) type of clamps, and g) measured and calculated parameters.

On the basis of systematic literature review, the mechanical properties determined for using with cooled clamps proved to be more reliable than room temperature and heated clamps. The main advantage is that there is no limit to the type and length of the tendon. The dry-ice clamp instead of liquid nitrogen is recommended for the clamping of tendons, because dry ice is cheaper to acquire than liquid nitrogen. Liquid nitrogen evaporates faster than dry ice. It is also easier to work with dry ice, permission is not needed for use, and it does not need to be stored in a container. In similar quantities, liquid nitrogen is colder than dry ice, which can harden the whole tendon, not just at the point of fixation.

Disadvantages of room temperature and heated tendons are that they can damage the tendon's texture and have a greater chance of slipping. During the measurement, a great force is created at capture, therefore an inaccurate result can be obtained. In the case of heated clamps, it should be taken into account that living tissue, when removed from the cadaver, begins to decay. This decay can be accelerated by the warm environment, which can lead to a distortion of the results. Since there is no unlimited amount of human tissue available, the most accurate measurement setup should be used.

\section{Abbreviations}

$A C L$ - Anterior cruciate ligament

\section{Declarations}

\section{Acknowledgements}

This work was supported by Hungarian National Research, Development and Innovation Office (NKFIH) through grant OTKA K116189 (Research project entitled "In vitro investigation of human tissues and definition of their mechanical materials models").

The research reported in this paper and carried out at Budapest University of Technology and Economics has been supported by the NRDI Fund TKP2020 NC, (Grant No. BME-NC) based on the charter of bolster issued by the NRDI Office under the auspices of the Ministry for Innovation and Technology, Hungary.

Acknowledgments to Gábor Szebényi PhD for reviewing this review article and Luca Faragó-Pethő for the figures.

\section{Ethics approval and consent to participate - Not applicable}

Consent for publication - Not applicable

Availability of data and materials - The data that support the findings of this study are available from authors of not open access journals but restrictions apply to the availability of these data, which were used under license for the current study, and so are not publicly available. Data are however available from Denes 
Farago upon reasonable request and with permission of authors of not open access journals. All data generated or analysed during this study are included in this published review.

Competing interests - The authors declare that they have no competing interests

Funding - The research reported in this paper was supported by the Higher Education Excellence Program of the Ministry of Human Capacities within the Biotechnology research area of Budapest University of Technology and Economics (BME FIKP-BIO). This research was supported by the National Research, Development and Innovation Office (OTKA K 116189).

The research reported in this paper and carried out at Budapest University of Technology and Economics has been supported by the NRDI Fund TKP2020 NC, (Grant No. BME-NC) based on the charter of bolster issued by the NRDI Office under the auspices of the Ministry for Innovation and Technology, Hungary.

Authors' contributions - DF, BK analyzed and interpreted the patient data regarding the hematological disease and the transplant. DF, RK performed the histological examination of the kidney and was a major contributor in writing the manuscript. All authors read and approved the final manuscript.

\section{References}

1. D. J. Zoltan, C. Reinecke, and P. A. Indelicato, "Synthetic and allograft anterior cruciate ligament reconstruction.," Clin. Sports Med., vol. 7, no. 4, pp. 773-84, Oct. 1988.

2. P. K. Nikolaou, A. V. Seaber, R. R. Glisson, B. M. Ribbeck, and F. H. Bassett, "Anterior cruciate ligament allograft transplantation,” Am. J. Sports Med., vol. 14, no. 5, pp. 348-360, Sep. 1986.

3. F. R. Noyes, S. D. Barber, and R. E. Mangine, "Bone-patellar ligament-bone and fascia lata allografts for reconstruction of the anterior cruciate ligament.," J. Bone Joint Surg. Am., vol. 72, no. 8, pp. 1125-36, Sep. 1990.

4. K. Shino, T. Kimura, H. Hirose, M. Inoue, and K. Ono, "Reconstruction of the anterior cruciate ligament by allogeneic tendon graft. An operation for chronic ligamentous insufficiency.," J. Bone Joint Surg. Br., vol. 68, no. 5, pp. 739-46, Nov. 1986.

5. R. A. Wainer, T. J. Clarke, and G. G. Poehling, "Arthroscopic reconstruction of the anterior cruciate ligament using allograft tendon," Arthrosc. J. Arthrosc. Relat. Surg., vol. 4, no. 3, pp. 199-205, Jan. 1988

6. C. D. Harner, E. Olson, J. J. Irrgang, S. Silverstein, F. H. Fu, and M. Silbey, "Allograft versus autograft anterior cruciate ligament reconstruction: 3- to 5-year outcome.," Clin. Orthop. Relat. Res., no. 324, pp. 134-44, Mar. 1996.

7. P. A. Indelicato, R. C. Linton, and M. Huegel, "The results of fresh-frozen patellar tendon allografts for chronic anterior cruciate ligament deficiency of the knee," Am. J. Sports Med., vol. 20, no. 2, pp. 118121, Mar. 1992.

8. S. K. Y. Chang, D. K. Egami, M. D. Shaieb, D. M. Kan, and A. B. Richardson, "Anterior cruciate ligament reconstruction: Allograft versus autograft," Arthrosc. J. Arthrosc. Relat. Surg., vol. 19, no. 5, pp. 453462, May 2003. 
9. C. Prodromos, B. Joyce, and K. Shi, "A meta-analysis of stability of autografts compared to allografts after anterior cruciate ligament reconstruction," Knee Surgery, Sport. Traumatol. Arthrosc., vol. 15, no. 7, pp. 851-856, Jul. 2007.

10. B. P. Conrad, M. Rappé, M. Horodyski, K. W. Farmer, and P. A. Indelicato, "The effect of sterilization on mechanical properties of soft tissue allografts," Cell Tissue Bank., vol. 14, no. 3, pp. 359-366, Sep. 2013.

11. C. R. Bottoni et al., "Autograft Versus Allograft Anterior Cruciate Ligament Reconstruction," Am. J. Sports Med., vol. 43, no. 10, pp. 2501-2509, Oct. 2015.

12. C. Crawford et al., "Investigation of Postoperative Allograft-Associated Infections in Patients Who Underwent Musculoskeletal Allograft Implantation," Clin. Infect. Dis., vol. 41, no. 2, pp. 195-200, Jul. 2005.

13. T. Schmidt et al., "Does sterilization with fractionated electron beam irradiation prevent ACL tendon allograft from tissue damage?," Knee Surgery, Sport. Traumatol. Arthrosc., vol. 25, no. 2, pp. 584- 594, 2017.

14. J. W. Genuario, S. C. Faucett, M. Boublik, and T. F. Schlegel, "A Cost-Effectiveness Analysis Comparing 3 Anterior Cruciate Ligament Graft Types," Am. J. Sports Med., vol. 40, no. 2, pp. 307-314, Feb. 2012.

15. J. Kartus, T. Movin, and J. Karlsson, "Donor-site morbidity and anterior knee problems after anterior cruciate ligament reconstruction using autografts," Arthrosc. J. Arthrosc. Relat. Surg., vol. 17, no. 9, pp. 971-980, Nov. 2001.

16. T. E. Mroz, M. J. Joyce, M. P. Steinmetz, I. H. Lieberman, and J. C. Wang, "Musculoskeletal allograft risks and recalls in the United States.," J. Am. Acad. Orthop. Surg., vol. 16, no. 10, pp. 559-65, Oct. 2008.

17. S. S.-H. Park, T. Dwyer, F. Congiusta, D. B. Whelan, and J. Theodoropoulos, "Analysis of Irradiation on the Clinical Effectiveness of Allogenic Tissue When Used for Primary Anterior Cruciate Ligament Reconstruction," Am. J. Sports Med., vol. 43, no. 1, pp. 226-235, Jan. 2015.

18. S. G. Tejwani, J. Chen, T. T. Funahashi, R. Love, and G. B. Maletis, "Revision Risk After Allograft Anterior Cruciate Ligament Reconstruction," Am. J. Sports Med., vol. 43, no. 11, pp. 2696-2705, Nov. 2015.

19. J. Wee and K. T. Lee, "Graft Infection following Arthroscopic Anterior Cruciate Ligament Reconstruction: A Report of Four Cases," J. Orthop. Surg., vol. 22, no. 1, pp. 111-117, Apr. 2014.

20. J. Tang, F. Zeng, H. Savage, P. P. Ho, and R. R. Alfano, "Laser irradiative tissue probed in situ by collagen 380-nm fluorescence imaging," Lasers Surg. Med., vol. 27, no. 2, pp. 158-164, 2000.

21. M. Pacifici, "Retinoid roles and action in skeletal development and growth provide the rationale for an ongoing heterotopic ossification prevention trial," Bone, vol. 109, pp. 267-275, 2018.

22. B. E. Buck, T. I. Malinin, and M. D. Brown, "Bone transplantation and human immunodeficiency virus. An estimate of risk of acquired immunodeficiency syndrome (AIDS).," Clin. Orthop. Relat. Res., no. 240, pp. 129-36, Mar. 1989.

23. E. R. Carlson, R. E. Marx, and B. E. Buck, "The potential for HIV transmission through allogeneic bone. A review of risks and safety.," Oral Surg. Oral Med. Oral Pathol. Oral Radiol. Endod., vol. 80, no. 1, pp. 1723, Jul. 1995. 
24. Centers for Disease Control and Prevention (CDC), "Septic arthritis following anterior cruciate ligament reconstruction using tendon allografts-Florida and Louisiana, 2000.," MMWR. Morb. Mortal. Wkly. Rep., vol. 50, no. 48, pp. 1081-3, Dec. 2001.

25. M. A. Kainer et al., "Clostridium Infections Associated with Musculoskeletal-Tissue Allografts," N. Engl. J. Med., vol. 350, no. 25, pp. 2564-2571, Jun. 2004.

26. A. Liberati et al., "The PRISMA Statement for Reporting Systematic Reviews and Meta-Analyses of Studies That Evaluate Health Care Interventions: Explanation and Elaboration," PLoS Med., vol. 6, no. 7, p. e1000100, Jul. 2009.

27. C. M. Aguila, G. J.-R. Delcroix, D. N. Kaimrajh, E. L. Milne, H. T. Temple, and L. L. Latta, “Effects of gamma irradiation on the biomechanical properties of peroneus tendons," Open Access J. Sport. Med., vol. 7, pp. 123-127, 2016.

28. T. Baldini, K. Caperton, M. Hawkins, and E. McCarty, "Effect of a novel sterilization method on biomechanical properties of soft tissue allografts," Knee Surgery, Sport. Traumatol. Arthrosc., vol. 24, no. 12, pp. 3971-3975, 2016.

29. C. R. Balsly, A. T. Cotter, L. A. Williams, B. D. Gaskins, M. A. Moore, and L. Wolfinbarger, "Effect of low dose and moderate dose gamma irradiation on the mechanical properties of bone and soft tissue allografts," Cell Tissue Bank., vol. 9, no. 4, pp. 289-298, 2008.

30. E. Y. Elenes and S. A. Hunter, "Soft-tissue allografts terminally sterilized with an electron beam are biomechanically equivalent to aseptic, nonsterilized tendons," J. Bone Jt. Surg. - Am. Vol., vol. 96, no. 16, pp. 1321-1326, 2014.

31. H. B. Colaço, B. R. Lord, D. L. Back, A. J. Davies, A. A. Amis, and A. Ajuied, "Biomechanical properties of bovine tendon xenografts treated with a modern processing method," J. Biomech., vol. 53, pp. 144-147, Feb. 2017.

32. L. L. Greaves, A. T. Hecker, and C. H. Brown, "The effect of donor age and low-dose gamma irradiation on the initial biomechanical properties of human tibialis tendon allografts," Am. J. Sports Med., vol. 36, no. 7, pp. 1358-1366, 2008.

33. J. E. Bechtold, D. T. Eastlund, M. K. Butts, D. F. Lagerborg, and R. F. Kyle, "The Effects of Freeze-drying and Ethylene Oxide Sterilization on the Mechanical Properties of Human Patellar Tendon," Am. J. Sports Med., vol. 22, no. 4, pp. 562-566, 1994.

34. A. D. Sobel, D. Hohman, J. Jones, and L. J. Bisson, “Chlorhexidine gluconate cleansing has no effect on the structural properties of human patellar tendon allografts," Arthrosc. - J. Arthrosc. Relat. Surg., vol. 28, no. 12, pp. 1862-1866, 2012.

35. D. B. Jones, P. M. Huddleston, M. E. Zobitz, and M. J. Stuart, “Mechanical Properties of Patellar Tendon Allografts Subjected to Chemical Sterilization," Arthrosc. J. Arthrosc. Relat. Surg., vol. 23, no. 4, p. 400404.e1, Apr. 2007.

36. L. Suhodolčan, M. Brojan, F. Kosel, M. Drobnič, A. Alibegović, and J. Brecelj, "Cryopreservation with glycerol improves the in vitro biomechanical characteristics of human patellar tendon allografts," Knee Surgery, Sport. Traumatol. Arthrosc., vol. 21, no. 5, pp. 1218-1225, 2013. 
37. P. De Deyne and R. C. Haut, "Some effects of gamma irradiation on patellar tendon allografts," Connect Tissue Res, vol. 27, no. 1, pp. 51-62, 1991.

38. A. R. Curran, D. J. Adams, J. L. Gill, M. E. Steiner, and A. D. Scheller, "The biomechanical effects of lowdose irradiation on bone-patellar tendon-bone allografts," Am. J. Sports Med., vol. 32, no. 5, pp. 11311135, 2004.

39. G. Gut, J. Marowska, A. Jastrzebska, E. Olender, and A. Kamiński, "Structural mechanical properties of radiation-sterilized human Bone-Tendon-Bone grafts preserved by different methods," Cell Tissue Bank., vol. 17, no. 2, pp. 277-287, 2016.

40. A. T. Hoburg et al., "Effect of Electron Beam Irradiation on Biomechanical Properties of Patellar Tendon Allografts in Anterior Cruciate Ligament Reconstruction," Am. J. Sports Med., vol. 38, no. 6, pp. 1134$1140,2010$.

41. T. J. Rasmussen, S. M. Feder, D. L. Butler, and F. R. Noyes, "The effects of 4 mrad of $y$ irradiation on the initial mechanical properties of bone-patellar tendon-bone grafts," Arthroscopy, vol. 10, no. 2, pp. 188$197,1994$.

42. A. E. Weber et al., "How Variable Are Achilles Allografts Used for Anterior Cruciate Ligament Reconstruction? A Biomechanical Study," Am. J. Sports Med., pp. 1-7, 2018.

43. W. Wei et al., "Fractionation of 50kGy electron beam irradiation: Effects on biomechanics of human flexor digitorum superficialis tendons treated with ascorbate," J. Biomech., vol. 46, no. 4, pp. 658-661, 2013.

44. D. Ren et al., "Effects of gamma irradiation and repetitive freeze-thaw cycles on the biomechanical properties of human flexor digitorum superficialis tendons," J. Biomech., vol. 45, no. 2, pp. 252-256, 2012.

45. C. Smith, I. Young, and J. Kearney, "Mechanical properties of tendons: changes with sterilization and preservation.," J. Biomech. Eng., vol. 118, no. 1, pp. 56-61, 1996.

46. H. B. Colaço, B. R. Lord, D. L. Back, A. J. Davies, A. A. Amis, and A. Ajuied, "Biomechanical properties of bovine tendon xenografts treated with a modern processing method," J. Biomech., vol. 53, pp. 144-147, 2017.

47. D. Bettin, V. Rullkötter, J. Polster, and S. Fuchs, "Primary biomechanical influence of different sterilization methods on a freeze-dried bone-ligament transplant," Arch. Orthop. Trauma Surg., vol. 119, no. 3-4, pp. 236-240, 1999.

48. T. Schmidt et al., "Sterilization with electron beam irradiation influences the biomechanical properties and the early remodeling of tendon allografts for reconstruction of the anterior cruciate ligament (ACL)," Cell Tissue Bank., vol. 13, no. 3, pp. 387-400, 2012.

49. K. C. McGilvray, B. G. Santoni, A. S. Turner, S. Bogdansky, D. L. Wheeler, and C. M. Puttlitz, “Effects of 60Co gamma radiation dose on initial structural biomechanical properties of ovine bone-patellar tendon-bone allografts," Cell Tissue Bank., vol. 12, no. 2, pp. 89-98, 2011.

50. D. Bettin, J. Polster, V. Rullkötter, R. Von Versen, and S. Fuchs, “Good preservation of initial mechanical properties in lipid-extracted, disinfected, freeze-dried sheep patellar tendon grafts," Acta Orthop. Scand., vol. 74, no. 4, pp. 470-475, 2003. 
51. M. Irani, V. Lovric, and W. R. Walsh, "Effects of supercritical fluid CO2 and $25 \mathrm{kGy}$ gamma irradiation on the initial mechanical properties and histological appearance of tendon allograft," Cell Tissue Bank., 2018.

52. A. Salehpour et al., "Dose-dependent response of gamma irradiation on mechanical properties and related biochemical composition of goat bone-patellar tendon-bone allografts," J. Orthop. Res., vol. 13, no. 6, pp. 898-906, 1995.

53. M. J. Gibbons, D. L. Butler, E. S. Grood, D. I. Bylski-Austrow, M. S. Levy, and F. R. Noyes, “Effects of gamma irradiation on the initial mechanical and material properties of goat bone-patellar tendon-bone allografts," J. Orthop. Res., vol. 9, no. 2, pp. 209-218, Mar. 1991.

54. F. M. Azar, "Tissue Processing: Role of Secondary Sterilization Techniques," Clin. Sports Med., vol. 28, no. 2, pp. 191-201, 2009.

55. A. Dziedzic-Goclawska, A. Kaminski, I. Uhrynowska-Tyszkiewicz, and W. Stachowicz, "Irradiation as a safety procedure in tissue banking," Cell Tissue Bank., vol. 6, no. 3, pp. 201-219, 2005.

56. G. Hangody, G. Szebényi, B. Abonyi, R. Kiss, and L. Hangody, "Does a different dose of gamma irradiation have the same effect on five different types of tendon allografts ? - a biomechanical study," pp. 357-365, 2017.

57. T. J. Rasmussen, S. M. Feder, D. L. Butler, and F. R. Noyes, "The effects of 4 Mrad of gamma irradiation on the initial mechanical properties of bone-patellar tendon-bone grafts.," Arthroscopy, vol. 10, no. 2 , pp. 188-97, Apr. 1994.

58. A. Schimizzi, M. Wedemeyer, T. Odell, W. Thomas, A. T. Mahar, and R. Pedowitz, "Effects of a Novel Sterilization Process on Soft Tissue Mechanical Properties for Anterior Cruciate Ligament Allografts," Am. J. Sports Med., vol. 35, no. 4, pp. 612-616, Apr. 2007.

59. A. Hoburg et al., "Fractionation of high-dose electron beam irradiation of BPTB grafts provides significantly improved viscoelastic and structural properties compared to standard gamma irradiation," Knee Surgery, Sport. Traumatol. Arthrosc., vol. 19, no. 11, pp. 1955-1961, 2011.

60. A. Hoburg et al., "High-dose electron beam sterilization of soft-tissue grafts maintains significantly improved biomechanical properties compared to standard gamma treatment," Cell Tissue Bank., vol. 16, no. 2, pp. 219-226, 2015.

61. D. B. Jones, P. M. Huddleston, M. E. Zobitz, and M. J. Stuart, "Mechanical Properties of Patellar Tendon Allografts Subjected to Chemical Sterilization," Arthrosc. - J. Arthrosc. Relat. Surg., vol. 23, no. 4, pp. 400-404, 2007.

62. A. Yanke, R. Bell, A. Lee, E. F. Shewman, V. Wang, and B. R. Bach, "Regional mechanical properties of human patellar tendon allografts," Knee Surgery, Sport. Traumatol. Arthrosc., vol. 23, no. 4, pp. 961-967, 2015.

63. T. E. Mroz et al., "Biomechanical analysis of allograft bone treated with a novel tissue sterilization process," Spine J., vol. 6, no. 1, pp. 34-39, 2006.

64. M. Zhou et al., "Tendon allograft sterilized by peracetic acid/ethanol combined with gamma irradiation," J. Orthop. Sci., vol. 19, no. 4, pp. 627-636, 2014. 
65. E. M. H. Gardner, N. VonderHeide, R. Fisher, G. Brooker, and P. J. Yates, “Effect of hydrogen peroxide on human tendon allograft," Cell Tissue Bank., vol. 14, no. 4, pp. 667-671, Dec. 2013.

66. G. Gut, J. Marowska, A. Jastrzebska, E. Olender, and A. Kamiński, "Structural mechanical properties of radiation-sterilized human Bone-Tendon-Bone grafts preserved by different methods," Cell Tissue Bank., vol. 17, no. 2, pp. 277-287, Jun. 2016.

67. J. Biskup, A. Freeman, W. Camisa, J. Innes, and M. Conzemius, "Mechanical Properties of Canine Patella-Ligament-Tibia Segment," Vet. Surg., vol. 43, no. 2, pp. 136-141, 2014.

68. A. Salehpour et al., “Dose-dependent response of gamma irradiation on mechanical properties and related biochemical composition of goat bone-patellar tendon-bone allografts," J. Orthop. Res., vol. 13, no. 6, pp. 898-906, 1995.

69. K. R. Swank, A. W. Behn, and J. L. Dragoo, "The Effect of Donor Age on Structural and Mechanical Properties of Allograft Tendons," Am. J. Sports Med., vol. 43, no. 2, pp. 453-459, 2015.

70. A. U. Seto, C. J. Gatt, and M. G. Dunn, “Sterilization of tendon allografts: A method to improve strength and stability after exposure to 50 kGy gamma radiation," Cell Tissue Bank., vol. 14, no. 3, pp. 349-357, 2013.

71. A. Maeda et al., "Effects of solvent preservation with or without gamma irradiation on the material properties of canine tendon allografts," J. Orthop. Res., vol. 11, no. 2, pp. 181-189, 1993.

72. L. M. Delgado, A. Pandit, and D. I. Zeugolis, "Influence of sterilisation methods on collagen-based devices stability and properties," Expert Rev. Med. Devices, vol. 11, no. 3, pp. 305-314, 2014.

73. D. A. Lansdown, A. J. Riff, M. Meadows, A. B. Yanke, and B. R. Bach, "What Factors Influence the Biomechanical Properties of Allograft Tissue for ACL Reconstruction? A Systematic Review," Clin. Orthop. Relat. Res., vol. 475, no. 10, pp. 2412-2426, 2017.

74. H. Nguyen, D. A. F. Morgan, and M. R. Forwood, "Sterilization of allograft bone: Effects of gamma irradiation on allograft biology and biomechanics," Cell Tissue Bank., vol. 8, no. 2, pp. 93-105, 2007.

75. A. C. DiBartola, J. S. Everhart, C. C. Kaeding, R. A. Magnussen, and D. C. Flanigan, “Maximum load to failure of high dose versus low dose gamma irradiation of anterior cruciate ligament allografts: A metaanalysis," Knee, vol. 23, no. 5, pp. 755-762, 2016.

76. T. A. Roberson et al., "Proprietary Processed’ Allografts: Clinical Outcomes and Biomechanical Properties in Anterior Cruciate Ligament Reconstruction," Am. J. Sports Med., vol. 45, no. 13, pp. 3158$3167,2017$.

77. Farago, D., Kozma, B. \& Kiss, R.M. Different sterilization and disinfection methods used for human tendons - a systematic review using mechanical properties to evaluate tendon allografts. BMC Musculoskelet Disord 22, 404 (2021).

\section{Figures}




\section{Image not available with this version}

Figure 1

The search of the database source gave 366 results. 


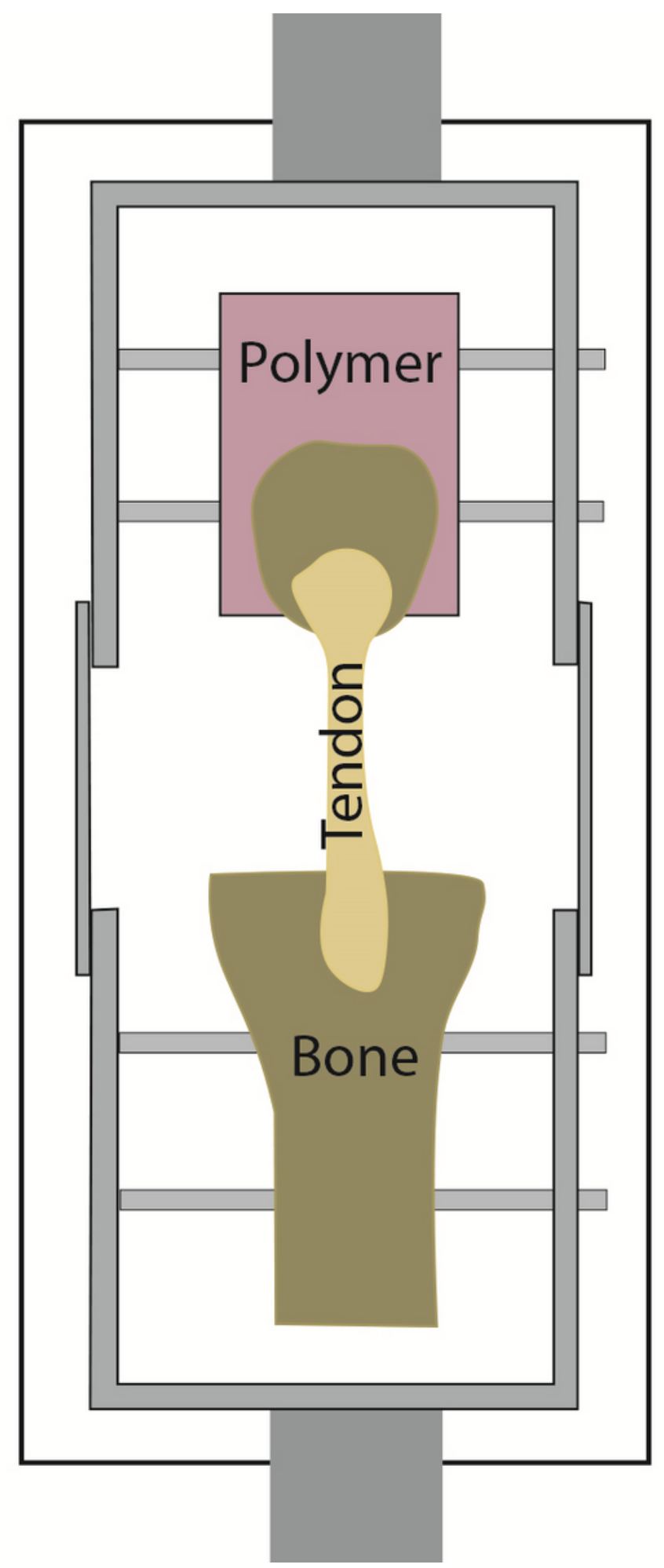

Figure 2

metal U-shaped frames [47], [50] 


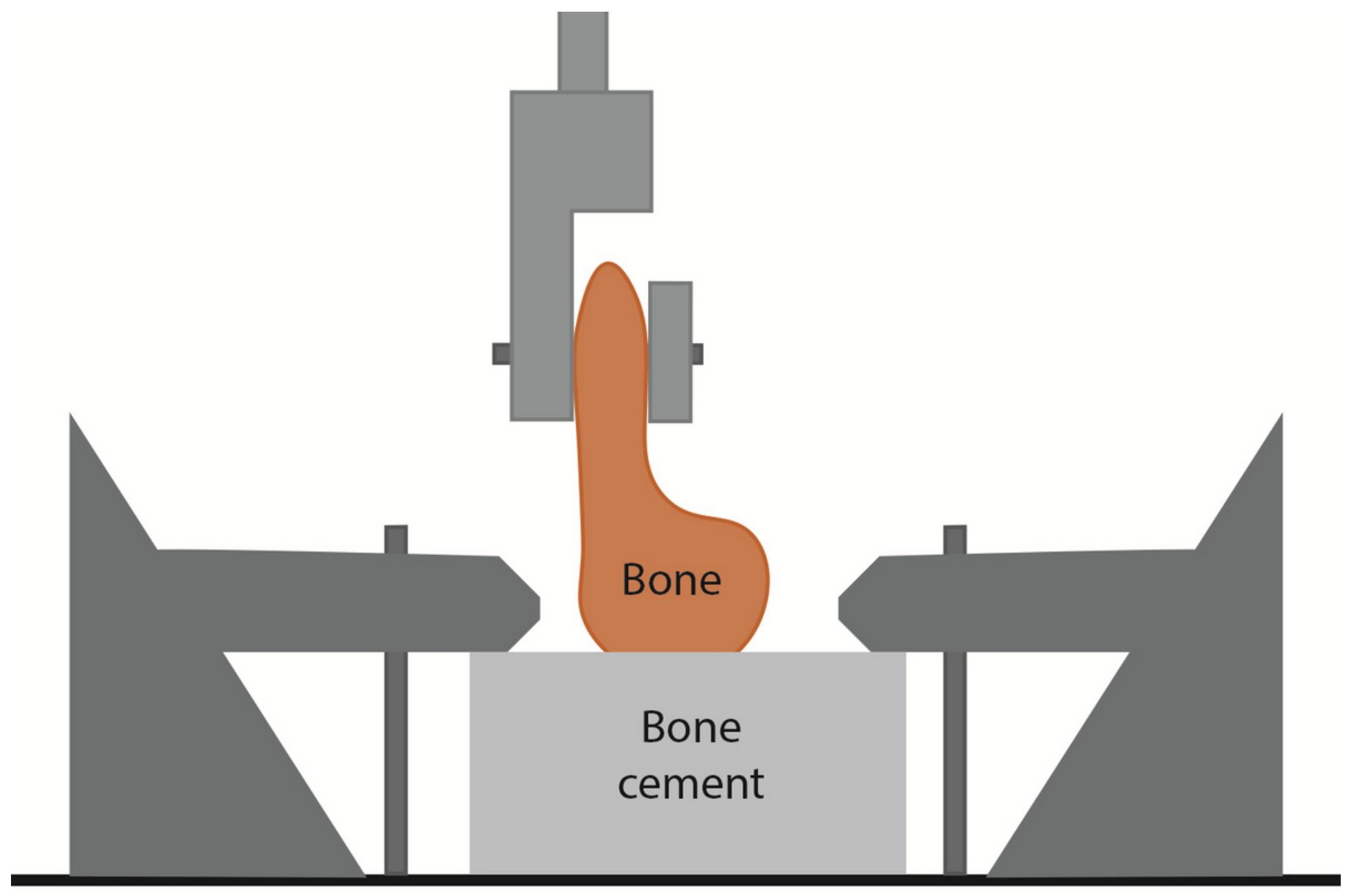

Figure 3

Custom-designed clamps for Canine PLT segments [67] 


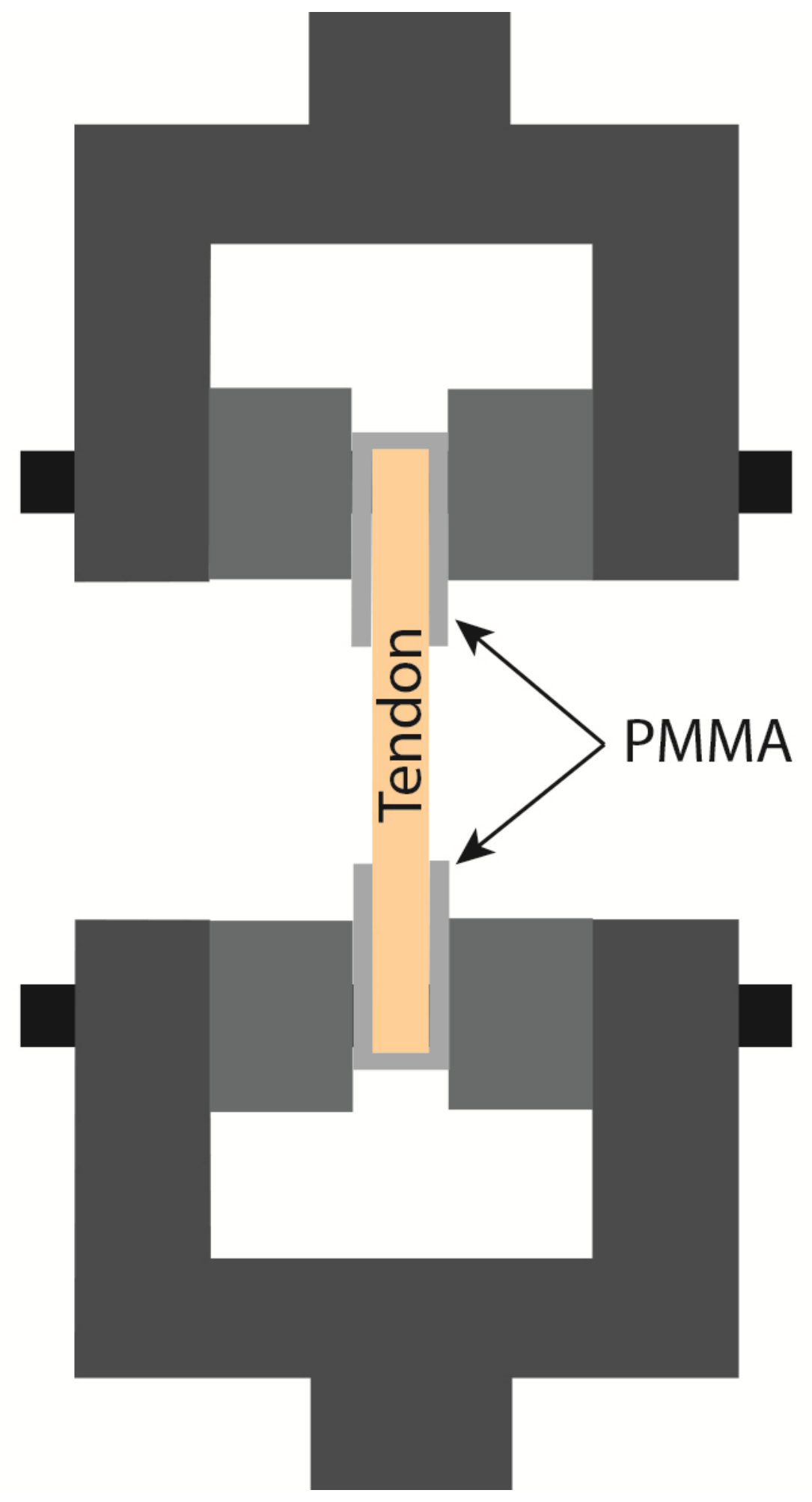

Figure 4

Images of factory clamps (Zwick/Roell) a) Osseus blocks potted in polyurethane fixed into the clamps of the testing device [36] 


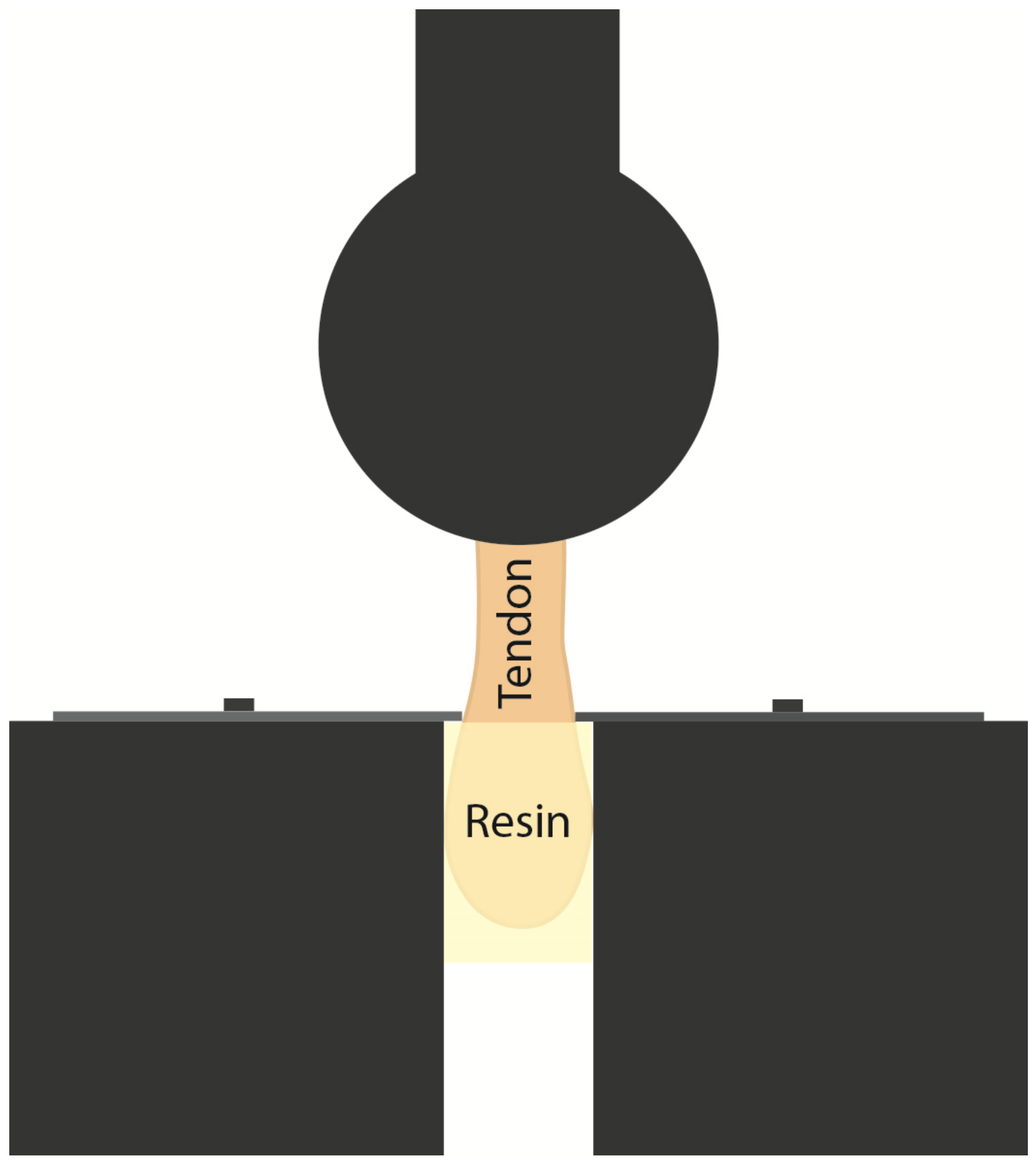

Figure 5

Wedge-shaped factory clamps [42] 


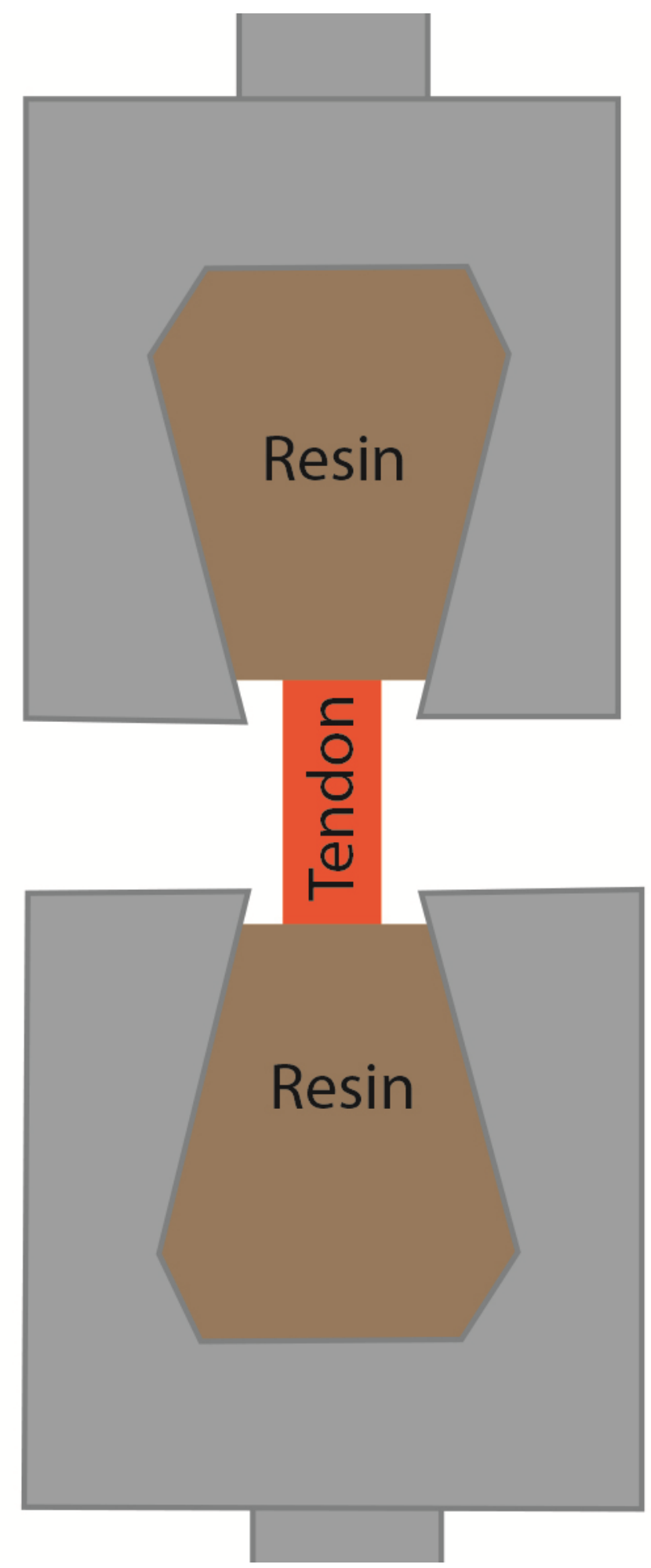

Figure 6

Wedge-grip clamps [34], [38] 


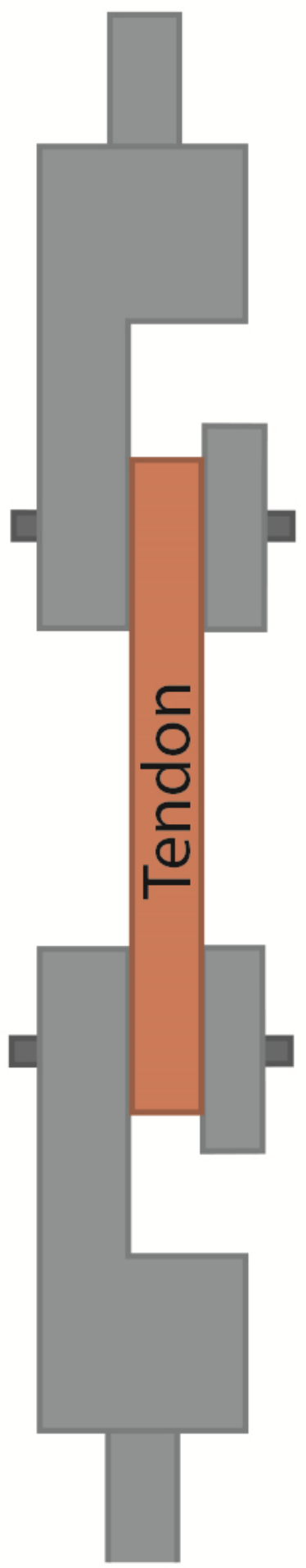

Figure 7

Aluminum grips with polymer liners and strain gauge [40], [59], [60] 


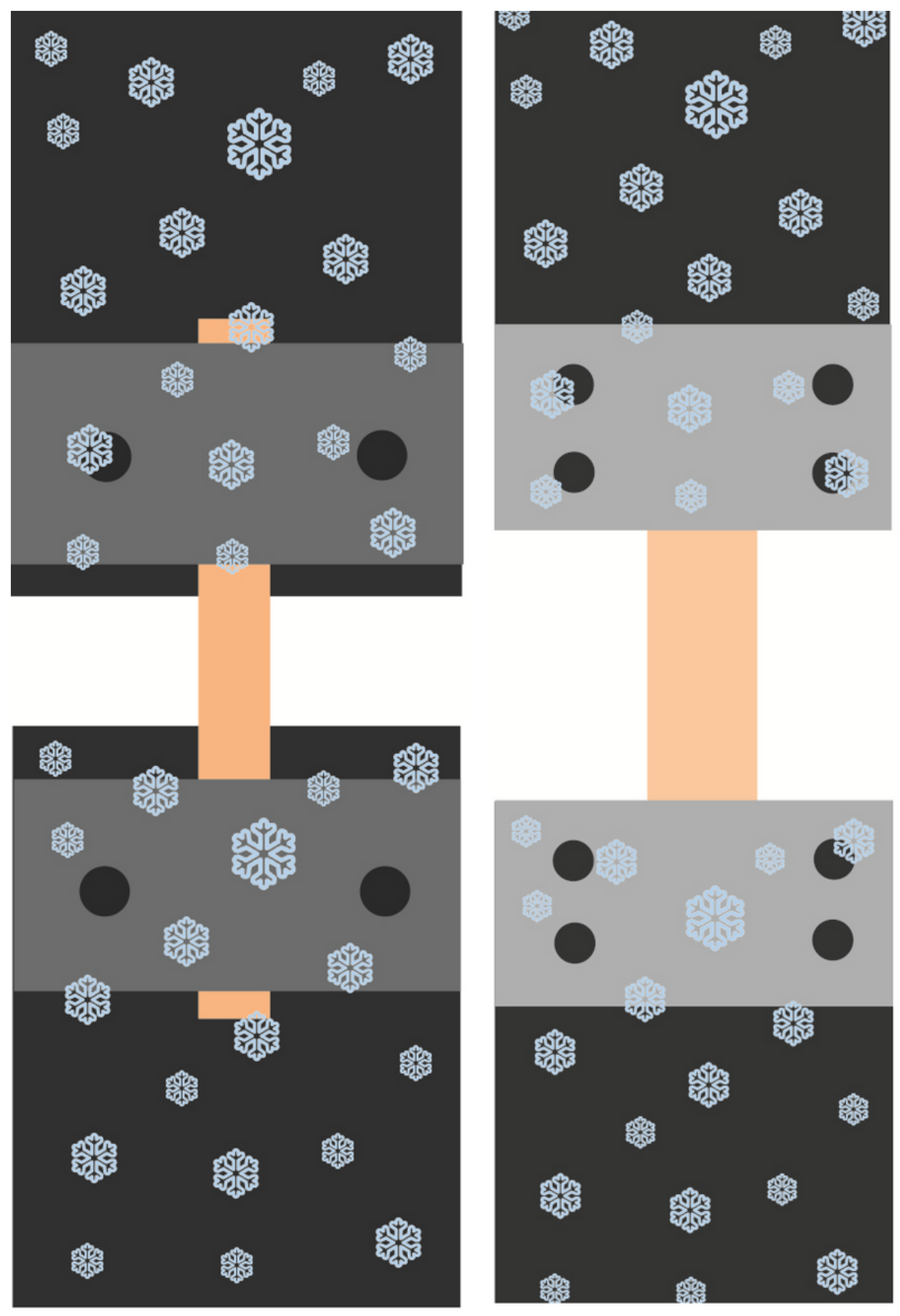

Figure 8

Testing configuration for single-row (a) and double-row (b) screw fixtures [32], [69] 

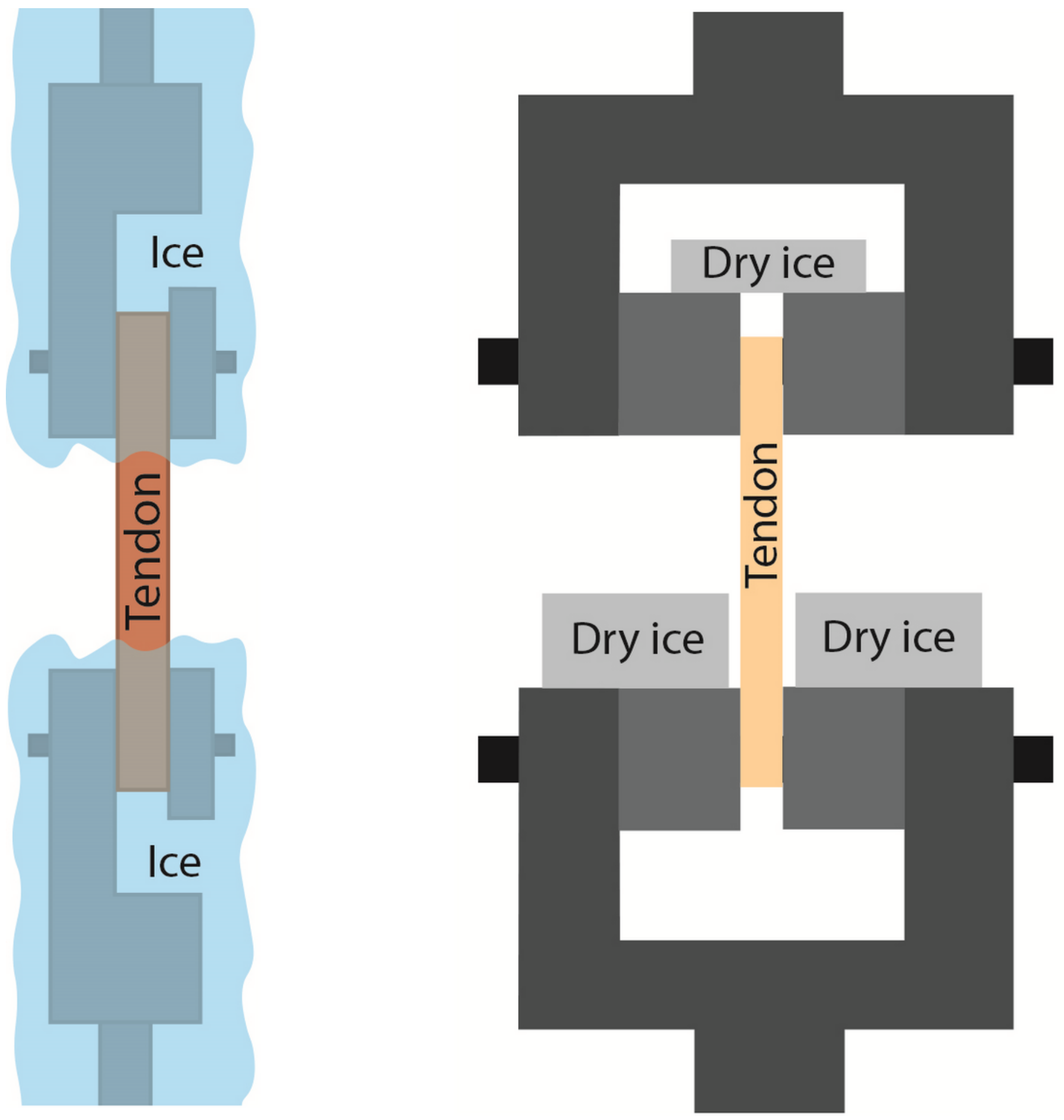

Figure 9

Cooled clamps with different ice chambers a) custom-designed clamp [28] b) factory clamp [65] 展

Figure 10

Screwed custom clamps with aluminium chamber for dry ice [56] 


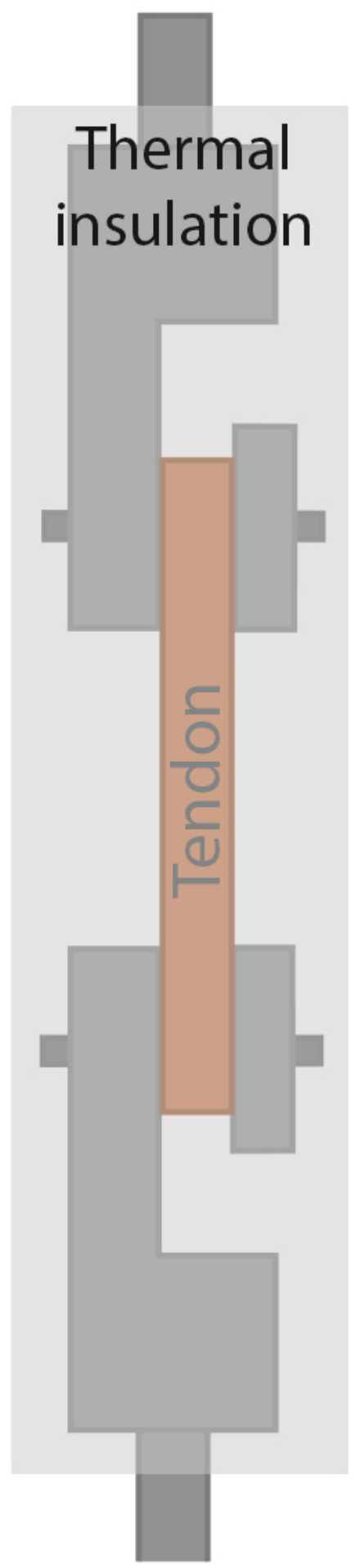

Figure 11

Test device with clamps, insulation, carbon composite rod, load cell, sample and thermocouple [37] 


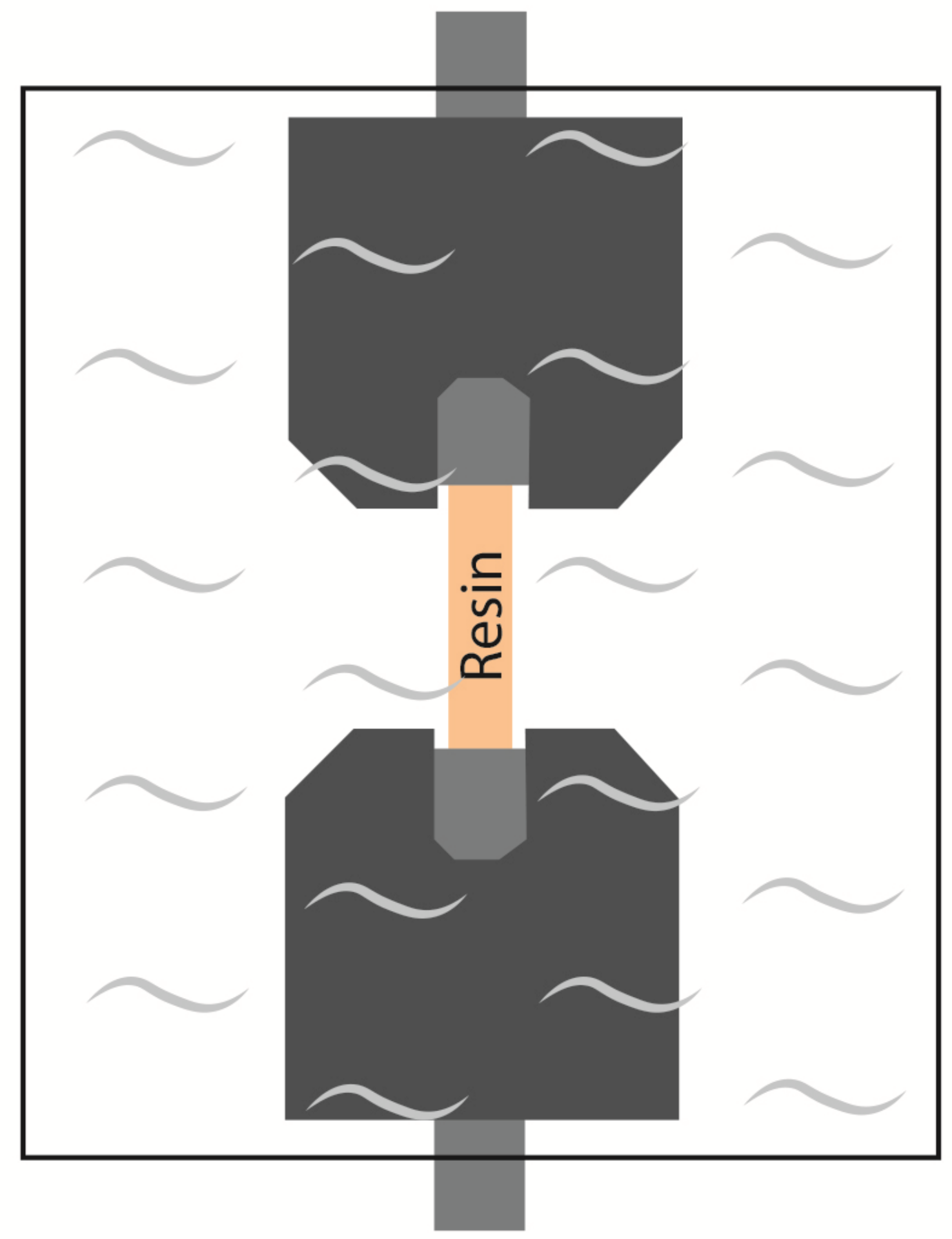

Figure 12

Testing chamber with a PTB specimen mounted in custom grips, showing. heaters used to maintain the phosphate buffered saline at $37^{\circ} \mathrm{C}$ [57] 


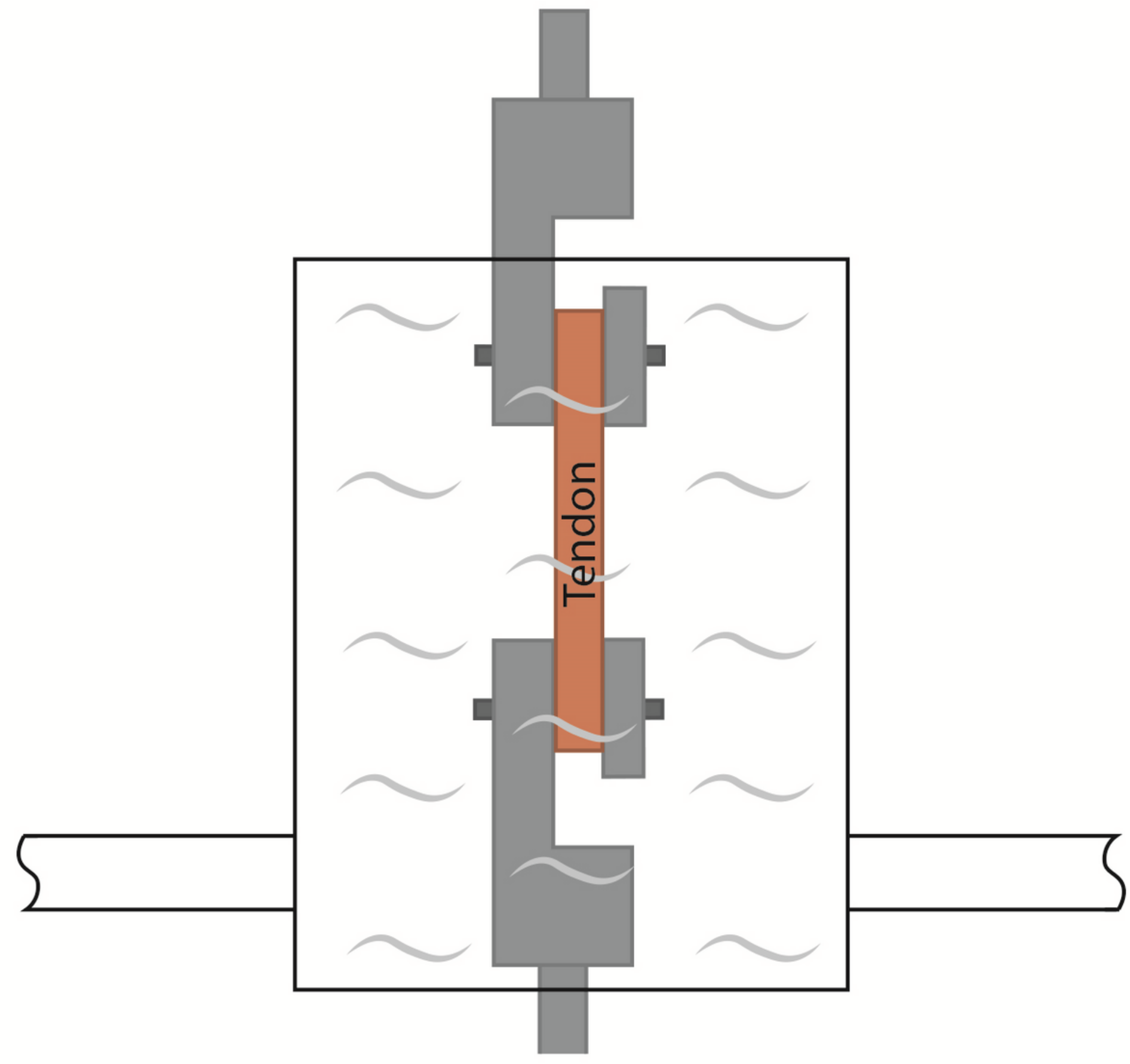

Figure 13

Biochamber used for cyclic loading in solution at $37^{\circ} \mathrm{C}[70]$

\section{Supplementary Files}

This is a list of supplementary files associated with this preprint. Click to download.

- PRISMAflowdiagramandchecklist.pdf 